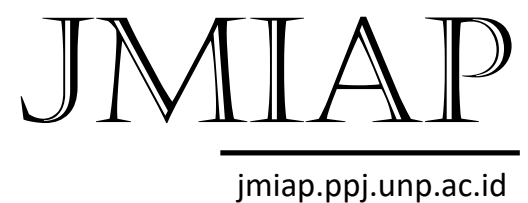

jmiap.ppj.unp.ac.id

Email : jianfis.unp@gmail.com

Vol.1 No.1 Tahun 2018

\title{
UPAYA BALAI BESAR PENGAWAS OBAT DAN MAKANAN (BBPOM) DI PADANG DALAM MENGAWASI PEREDARAN MAKANAN KEMASAN
}

\author{
Desi Arisanti \\ Jurusan Administrasi Publik, Fakultas Ilmu Sosial Universitas Negeri Padang \\ Email:desiarisanti0812@gmail.com \\ Dasman Lanin \\ Jurusan Administrasi Publik, Fakultas Ilmu Sosial, Universitas Negeri Padang \\ dasmanlanin@gmail.com \\ Jumiati \\ Jurusan Administrasi Publik, Fakultas Ilmu Sosial, Universitas Negeri Padang \\ upikjumiati@yahoo.com
}

\begin{abstract}
This study discusses how the efforts of the Food and Drug Supervisory Agency (BBPOM) in Padang to oversee the circulation of packaged food, as well as see how the supervision and obstacles faced by BBPOM to overcome this circulation.In reality, there were still various packaging foods that were dangerous to consumefound in the Padang City, such as expiration, the useof hazardous materials, illegal marketing authorization, etc. This study used descriptive qualitative method. Data in this study were collected through observation, interview, and documentation study. Informants in this study were determined through purposive sampling technique. Then the data were analyzed with interactive analysis model consisted of data collection, data reduction, data classification, data presentation and conclusion/verification. The results of this research showed that various efforts had been carried out by BBPOM in Padang to supervise the outstanding packaged foods, but this monitoring effort had not run optimally. This could be seen from the fact that the BBPOM still found some shops (stores) in the PadangCity, which was selling expired or illegal goodsand without legal distribution licenses.
\end{abstract}

Keywords: Supervision, packaging food, illegal distribution 


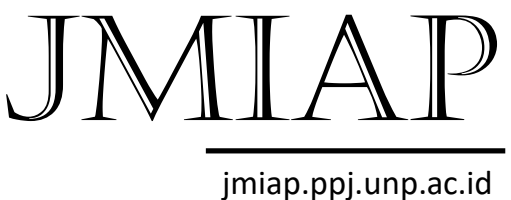

jmiap.ppj.unp.ac.id
ILMU ADMINISTRASI PUBLIK

Email : jianfis.unp@gmail.com Vol.1 No.1 Tahun 2018

\section{Pendahuluan}

Perkembangan dunia saat ini ditandai dengan arus globalisasi disegala bidang yang membawa dampak cukup pesat bagi perkembangan perekonomian Indonesia. Sejalan dengan dinamika lingkungan strategis, konsumsi masyarakat terhadap produk-produk instan cenderung terus meningkat pula. Kemajuan teknologi informasi dan produksi dibidang obat dan makanan akan semakin meningkat seiring dengan perkembangan ilmu pengetahuan. Hal ini juga membawa perubahan yang cukup besar pada gaya hidup konsumsi masyarakat. Perubahan gaya hidup konsumen pada realitanya dapat menimbulkan resiko pada kesehatan dan keselamatan konsumen, karena tidak semua bahan makanan siap saji dan yang sudah dibungkus yang dipasarkan memenuhi ketentuan dan standar untuk dipasarkan. Cara produksi dan peredaran makanan yang tidak aman dapat merugikan dan membahayakan kesehatan masyarakat. Tingginya minat dan konsumsi masyarakat terhadap makanan yang siap saji atau makanan kemasan juga memicu bermunculnya berbagai produsen yang memproduksi berbagai makanan, sehingga masyarakat juga disunguhkan dengan berbagai rasa dan berbagai bentuk. Tidak sedikit produsen yang memasarkan produknya yang tanpa izin edar. Agar konsumen terlindungi dalam hal ini adalah masyarakat, baik dari segi produksi, peredaran dan penggunaan sediaan farmasi dan makanan yang tidak memenuhi persyaratan mutu, kadaluarsa, dan keamanan makanan atau makanan yang tidak layak untuk dikonsumsi, sebagaimana kewajiban negara dalam melindungi masyarakatnya.
Peraturan Kepala Badan Pengawas Obat dan Makanan RI Nomor 12 Tahun 2016 tentang Pendftaran Pangan Olahan menjelaskan bahwa yang dimaksud dengan pangan adalah segala sesuatu yang berasal dari sumber hayati produk pertanian, perkebunan, kehutanan, perikanan, peternakan, perairan, dan air, baik yang diolah maupun yang tidak diolah, yang diperuntukkan sebagai makanan atau minuman bagi konsumsi mausia termasuk bahan tambahan pangan, bahan baku pangan, dan bahan lainnya yang digunakan dalam proses penyiapan, pengolahan, dan/atau pembuatan makanan atau minuman. Adapun yang diawasi oleh BPOM salah satunya adalah pangan olahan pabrik yang dijadikan makanan atau minuman instan atau siap saji (makanan kemasan). Makanan tersebut seperti mie, makanan ringan kemasan, susu, kripik balado, dan makanan kemasan lainnya yang diawasi oleh BPOM produk yang memenuhi ketentuan. Dalam makanan tersebut yang diawasi adalah bahan campuran masakannya,izin edar, label, kemasan dan batas kadaluarsa.

BBPOM di Padang yang mempunyai tugas utama sebagai pengawas harus berupaya semaksimal mungkin untuk mengawasi peredaran dan keamanan makanan yang beredar di Kota Padang. Pengawasan merupakan salah satu fungsi manajemen yang harus dijalankan oleh suatu organisasi. Pengawasan menurut G.R.Terry yang dikutip oleh Donni Juni Priansa dan Agus Garnida (2013) adalah suatu upaya yang sistematis untuk menentukan atau melihat apakah ada penyimpangan yang terjadi dan mengabil tindakan perbaikan-perbikan yang diperlukan unuk menjamin dan tercapainya sebuah organisasi. Adapun fungsi pengawasan adalah untuk mencegah 


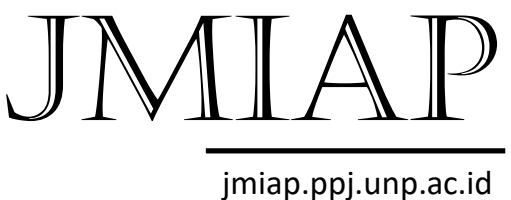

jmiap.ppj.unp.ac.id
ILMU ADMINISTRASI PUBLIK

Email : jianfis.unp@gmail.com

Vol.1 No.1 Tahun 2018 penyelewengan dan segala sesuatu yang tidak diinginkan terjadi agar produktivitas kerja bisa berjalan sesuai dengan rencana yang telah ditetapkan sebelumnya, serta mencegah penyalahgunaan kedudukan bagi pegawainya.

Fungsi pengawasan selain untuk melihat penyelewengan yang terjadi, pengawasan ini juga dilakukan untuk melihat hasil pekerjaan sesuai atau tidak dengan rencana awal, serta mengetahui budget yang di tetapkan digunakan untuk keperluan pekerjaan. Pengawasan memang sangat perlu dilaksanakan dalam menjankan sebuah pekerjaan, pengawasan ini berfungsi untuk mengevaluasi pncapaian target kerja sesuai dengan apa yang telah ditetapkan sebelumnya serta mencari solusi untuk memperbaiki apabila sudah terjadi penyimpangan. Dengan adanya permasalahan tersebut maka peneliti ingin mengetahui bagaimana pengawasan BBPOM di Padang terhadap kelayakan makanan yang beredar di Kota Padang. Badan Pengawas Obat dan makanan (BPOM) merupakan sebuah lembaga non kementrian yang bertugas mengawasai peredaran obat, obat tradisional, suplemen kesehatan, kosmetik dan makanan diwilayah indonesia.

Berdasarkan latar belakang masalah diatas, untuk itu penulis telah melakukan penelitian di BBPOM di Padang tentang upaya BBPOM di Padang dalam mengawasi peraedaran makanan kemasan yang beredar. Rumusan masalah pada penelitian ini terletak pada: 1) Bagaimana pengawasan kelayakan makanan kemasan oleh balai besar pengawas obat dan makanan (BBPOM) di Padang ?, 2) apa saja kendalakendala yang dihadapi oleh BBPOM dalam melaksanakan pengawasan terhadap kelayakan makanan kemasan yang beredar di Padang?, 3) Apa saja upaya yang dilakukan oleh BBPOM untuk meminimalisir kendala-kendala tdalam pengawasan?. Adapun tujuan penelitian ini adalah: 1) Untuk mengetahui bagaimana pengawasan BBPOM terhadap makanan kemasan yang beredar, 2) Untuk mengetahui kendala apa saja yang dihadapi oleh BBPOM, 3) Untuk mengetaui upaya yang dilakukan BBPOM dalam masalah pengawasan.

\section{Tinjauan Kepustakaan}

\section{Pengawasan}

Sondang P. Siagian (dalam Silalahi, 1999) mendefinisikan bahwa pengawasan adalah mengamati pelaksanaan seluruh kegiatan organisasi apakan pekerjaan berjalan sesuai dengan yang direncanakan, dan dimaksudkan untuk mencegah terjadinya penyimpangan dalam kegiatan yang sudah direncanakan.Robins dan Coulter mendefinisikan bahwa pengawasan adalah mengawasi aktivitas-aktivitas demi untuk memastikan segala sesuatu pekerjaan berjalan dan terselesaikan sesuai dengan rencana yang telah ditetapkan.

Selanjutnya Henry Fayol (dalam Sarwoto, 1995) mengartikan pengawasan sebagai suatu tindakan meneliti atau melihat apakah suatu kegiatan kebijakan sesuai dengan yang telah ditetapkan berdasarkan instruksi yang telah dikeluarkan dan prinsip yang telah ditetapkan. Pengawasan ini dilakukan untuk menemukan kelemahan-kelemahan agar kelemahan tersebut bisa diperbaiki secepat mungkin dan mencegah kelemahan tersebut terulang lagi. Pengawasan ini berpotensi untuk segala hal, baik terhadap benda ataupun terhadap manusia, perbuatan maupun hal-hal lainnya.

Dari beberapa penjelasan diatas dapat disimpulkan bahwa pengawasan 


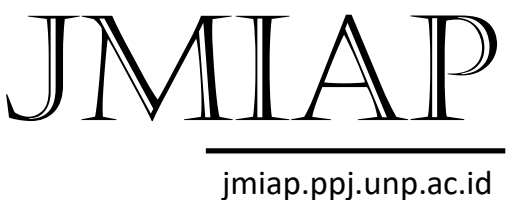

jmiap.ppj.unp.ac.id
ILMU ADMINISTRASI PUBLIK

Email : jianfis.unp@gmail.com Vol.1 No.1 Tahun 2018 adalah proses yang dilakukan untuk menghindari penyimpanganpenyimpangan yang mungkin akan terjadi sekaligus melakukan tindakan perbaikan apabila penyimpangan sudah terjadi. Pengawasn juga menjadi pengukur dan perbaikan kegiatan-kegiatan bawahan untuk menjamin bahwa kegiatan yang sedang dijalankan sesuai dengan rencana yang telah ditetapkan sebelumnya.

\section{Tujuan, Fungsi, dan Jenis Pengawasan}

Tercapainya tujuan organisasi sebenarnya juga tercapainya tujuan dari pengawasan. Oleh karena itu pengawasan sangat diperlukan dalam pencapaian tujuan sebuah organisasi. Menurut Syamsi (dalam Syamsir, 2013) tujuan pengawasan adalah sebagai berikut:(a) Untuk mengetahui apakah program yang telah dibuat sebelumnya mengalami kendala, (b) Untuk mengetahui apakah pelaksanaan program cukup efisien, (c) Untuk mengetahui penyebeb apabila terjadi penyimpangan, (d) Untuk mencari solusi dari kendala yang terjadi, sehingga pelaksanaan berjalan sesuai dengan perencanaan. Tujuan organisasi dapat tercapai jika pengawasan dilakukan sebelum terjadinya penyimpangan-penyimpangan karna bersifat mencegah.

Adapun fungsi pengawasan adalah untuk mencegah penyelewengan dan segala sesuatu yang tidak diinginkan terjadi agar produktivitas kerja bisa berjalan sesuai dengan rencana yang telah ditetapkan sebelumnya, serta mencegah penyalahgunaan kedudukan bagi pegawainya. Fungsi pengawasan selain untuk melihat penyelewengan yang terjadi, pengawasan ini juga dilakukan untuk melihat hasil pekerjaan sesuai atau tidak dengan rencana awal, serta mengetahui budget yang di tetapkan digunakan untuk keperluan pekerjaan. Pengawasan memang sangat perlu dilaksanakan dalam menjankan sebuah pekerjaan, pengawasan ini berfungsi untuk mengevaluasi pncapaian target kerja sesuai dengan apa yang telah ditetapkan sebelumnya serta mencari solusi untuk memperbaiki apabila sudah terjadi penyimpangan.

Banyak jenis pengawasan yang dilakukan untuk mengawasai setiap kegiatan agar tidak terjadi penyimpangan, Mariangan dalam Gaery (2014), pengawasan terbagi menjadi 4 yaitu:

a. Pengawasan dari dalam perusahaan. Pengawasan yang dilakukan oleh atasan untuk mengumpulkan data atau informasi yang diperoleh oleh peruahaan untuk menilai kemajuan dan kemunduran perusahaan.

b. Pengawasan dari luar perusahaan. Pengawasan yang dilakukan oleh unit diluar perusahaan untuk kepentingan tertentu.

c. Pengawasan preventif. Pengawasan yang dilakukan sebelum rencana itu dilaksanakan, dengan tujuan agar tidak terjadi kesalahan, kekeliruan dalam pelaksanaan kerja.

d. Pengawasan reprensif. Pengawasan yang dilakukan setelah adanya pelaksanaan pekerjaan agar hasilnya sesuai dengan perencanaan.

Berbagai pengawasan yang dilakukan oleh setiap atasan adalah agar pekerjaan bawahan dapat berjalan sesuai dengan apa yang telah ditetakan sebelumnya, pengawasan ini dilakukan mulai dari dalam perusahaan melalui pengumpulan data dan informasi guna untuk menilai kemajuan dan kemunduran perusahaan.

Sutarto (2012) dalam bukunya yang berjudul Dasar-dasar Kepemimpinan Administrasimengemukakan jenis-jenis

Desi Arisanti, Dasman Lanin, Jumiati |15 


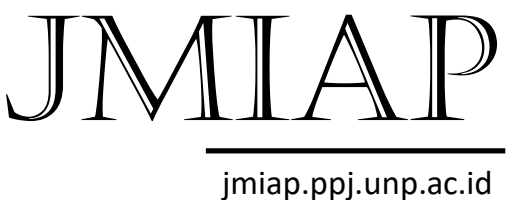

jmiap.ppj.unp.ac.id
ILMU ADMINISTRASI PUBLIK

Email : jianfis.unp@gmail.com Vol.1 No.1 Tahun 2018 pengawasan dilihat dari segi waktu yaitu sebagai berikut :

1. Kontrol preventif, yaitu kontrol yang dilakukan sebelum terjadinya penyimpangan.

2. Konrtol reprensif, yaitu kontrol yang dilakukan setelah terjadi penyimpangan.

3. Kontrol in-process, yaitu kontrol yang dilakukan saat terjadinya penyimpangan.

4. Kontrol berkala, yaitu kontrol yang dilakukan dengan selang waktu tetap. Misalnya kontrol mingguan, bulanan, tengah tahunan, tahunan.

5. Kontrol setiap saat, yaitu kontrol yang dilakukan dengan selang waktu tidak menentu.

dari jenis-jenis pengawasan yang dikemukakan diatas dapat diketahui bahwa pengawasan merupakan kegiatan oleh instansi dalam menalisir kesalahan atau penyimpangan. Dengan demikian kegiatan yang telah ditetapkan sebelumnya dapat berjalan dengan baik, dan melalui kegiatan pengawasan akan memberikan informasi yang cepat untuk selanjutnya untuk diambil langkah-langkah perbaikan atas penyimpangan yang terjadi.

Banyak jenis pengawasan yang dilakukan untuk mengawasai setiap kegiatan agar tidak terjadi penyimpangan, adapun jenis pengawasan BBPOM dalam melukan pengawasan adalah pengawasan pre market dan pengawasan post market. Pengawasan pre market adalah pengawasan yang dilakukan sebelum makanan kemasan beredar, sedangkan pengawasan post market adalah pengawasan yang dilakukan selama makanan kemasan beredar di tengah masyarakat.

\section{Sifat dan Waktu Pengawasan}

Menurut hasibuan (2001), sifat dan waktu pengawasan terdiri dari:

1. Preventive controll, pengendalian yang dilakukan sebelum kegiatan dilakukan untuk menghindari terjadinya penyimpangan-penyimpangan dalam pelaksanaannya. Preventive ini dilakukan dengan cara:

a. Menentukan proses pelaksanaan pekerjaan.

b. Membuat peraturan dan pelaksanaan pekerjaan.

c. Menjelaskan dan atau mendemonstrasikan cara pelaksanaan pekerjaan.

d. Mengorganisasi segala macam kegiatan.

e. Menentukan jabatan, job description, authority dan responsibility bagi setiap individu karyawan.

f. Menetapkan sistem koordinasi pelaporan dan pelaksanaan.

g. Menetapkan sanksi-sanksi bagi karyawan yang membuat kesalahan.

Preventive controll, merupakan pengendalian yang baik karana dilakukan sebelum penyimpangan terjadi.Preventive controll ini dilakukan dengan menetapkan beberapa cara sebelum pengawasan dilaksanakan.

2. Repressive controll, adalah pengendalian yang dilakukan sesudah rerjadinya kesalahan atau penyelewengan dalm pelaksanaan, dengan maksud agar tidak terjadi pengulangan kesalahan, sehingga hasilnya sesuai dengan yang diinginkan. Repressive controll dilakukan dengan cara sebagai berikut :

a. Membandingkan hasil dengan rencana.

b. Menganalisis sebab-sebab yang menimbulkan kesalahan dan mencari tindakan perbaikannya. 
c. Memberikan penilaian terhadap pelaksanaannya, jika perlu diberi sanksi hukum kepadanya.

d. Menilai kembali pelaksanaan prosedur-prosedur yang ada.

e. Mengecek kebenaran laporan yang dibuat yang dibuat oleh petugas pelaksana.

f. Jika perlu meningkatkan keterampilan atau kemampuan pelaksanaan melalui training atau education.

3. Pengawasan saat proses dilaksanakan yaitu jika terjadi kesalahan langsung diperbaiki.

4. Pengawasan berkala, yaitu pengawasan yang dilakukan secara berkala, misalnya perbulan atau pertahun.

5. Pengawasan mendadak, merupakan pengawasan yang dilakukan secara mendadak untuk mengetahui apakah pelaksanaan atau peraturan-peraturan yang ada telah dilaksanakan dengan baik. Pengawasan mendadak ini sekalisekali perlu dilakukan, supaya kedisiplinan karyawan tetap terjagadengan baik.

6. Pengawasan melekat, adalah pengawasan yang dilakukan ecara integratif, mulai dari sebelum, pada saat, dan sesudah kegiatan operasional dilakukan.

Berdasarkan pendapat yang dikemukakan oleh Hasibuan diatas maka dapat dilihat bahwa pengawasan yang baik adalah pengawasan yang memiliki tahapantahapan tertentu sebagai bentuk dari proses kegiatan pengawasan, selain itu juga memiliki waktu-waktu tertentu dalam proses pengawasan agar kegiatan berjalan sesuai dengan rencana dan tujuan organisasi dapat berjalan dengan efektif dan efisien. Sifat dan waktu dan pengawasan ini dilakukan sesuai dengan kebutuhan perusahaan.

Sifat dan waktu pengawasan yang tepat untuk melakukan pemeriksaan terhadap makanan kemasanyang beredar adalah preventif kontrol, yaitu pengawasan yang dilakukan sebelum penyimpangan terjadi, dan pengawasan mendadak, yaitu pengawasan yang dilakukan secara mendadak oleh tim pengawas untuk mengetahui apakah peraturan yang telah dibuat dapt terlaksana dengan baik dan benar.

\section{Langkah-langkah dalam Pengawasan}

Berdasarkan Peraturan Kepala Badan Pengawas Obat dan Makanan Tahun 2015 tentang Rencana Strategis Badan Pengawas Obat dan Makanan tahun 20152019, adapun langkah-langkah yang dilakukan BPOM dalam melakukan pengawasan terhadap makanan yang beredar yaitu: (1) Standarisasi makanan kemasan, merupakan penyusunan standar terkait dengan pengawasan obat dan makanan, standarisasi dilakukan BPOM pusat dengan tujuan untuk menghindari perbedaan standar yang mungkin terjadi akibat setiap Provinsi membuat standar tersendiri. (2) Penilaian yaitu pengawasan yang dilakukan sebelum memperoleh nomor izin edar. (3) Pengawasan selama produk beredar dilakukan untuk melihat konsistensi mutu produk, keamanan dan informasi produk, yang dilakukan dengan melakukan sampling produk makanan yang beredar, serta melakukan pengawasan label/penandaan dan iklan. (4) pengujian laboraturium. Produk yang disampling berdasarkan resiko kemudian diuji kembali melalui laboraturium agar diketahui apakah makanan tersebut telah memenuhi standar keamanan yang telah ditetapkan sebelumnya, hasil uji laboraturium ini 


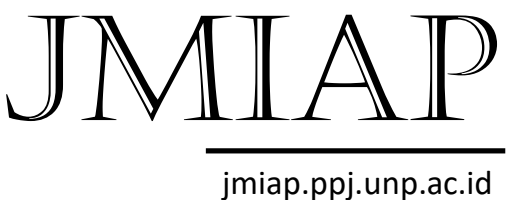

jmiap.ppj.unp.ac.id
ILMU ADMINISTRASI PUBLIK

Email : jianfis.unp@gmail.com Vol.1 No.1 Tahun 2018 digunakan untuk menetapkan produk tidak memenuhi syarat yang digunakan untuk ditarik dari peredaran. (5) Penegakan hukum dibidang pengawas obat dan makanan. Penegakan hukum didasarkan atas bukti hasil pengujian, pemeriksaan, maupun hasil investigasi awal. Proses penegakan hukum sampai dengan projusticia dapat berakhir dengan pemberian sanksi administratif seperti produk dilarang untuk diedarkan, ditarik dari peredaran, dicabut izin edar, disita untuk dimusnahkan. Jika pelanggaran yang dilakukan termasuk pada pidana, maka terhadap pelanggaran obat dan makanan dapat diproses secara hukum pidana.

Berdasarkan peraturan diatas dapat dilihat bahwa dalam melakukan pengawasan BBPOM meyusun atau menetapkan langkah-langkah untuk melakukan pengawasan agar pengawasan tersebut bisa dilakukan secara teratur.Selanjutnya Silalahi (1999) mengemukakan langkah-langkah dalam pengawasan adalah sebagai berikut :

a. Menentukan objek-objek yang akan diawasi. Objek-objek yang akan diawasi perlu perlu ditentukaan dengan skala prioritas sesuai dengan urgrnisitas proses pelaksanaan suatu rencana atau faktor-faktor strategis yang menentukan berhasil tidaknya suatu rencana.

b. Menetapkan standar sebagai alat ukur pengawasan atau yang menggambarkan pekerjaan yang dikehendaki.

c. Menentukan prosedur, waktu dan teknik yang dipergunakan.

d. Mengukur hasil kerja yang diaksanakan. Mengukur hasil kerja atau pelaksanaan kerja dapat dilakukan oeh manejer atau administrator berdasarkan informasi melalui : observasi personil, laporan-laporan statistik, laporan-laporan lisan, laporan-laporan tulisan.

e. Membandingkan hasil kerja dengan standar untuk mengetahui apakah ada perbedaan. Pembandinagan dilakukan untuk menentuakn tingkat perbedaan antara pelaksanaan (hasil) kerja yang dicapai dengan apa yang diinginkan sebelumnya (rencan).

f. Melakukan tindakan-tindakan perbaikan terhadap suatu penyimpangan atau penyimpanganpenyimpangan yang berarti.

Berdasarkan hal yang disampaikan diatas maka dapat dilihat bahwa untuk mencapai tujuan organisasi maka sangat diperlukan langkah-langkah dalam pelaksanaan pengawasan. Langkahlangkah ini mengusahakan agar pelaksanaan pengawasan berjalan dengan baik sesuai dengan yang ditentukan dalam rencana dan bisa juga melihat dan membandingkan hasil kerja dengan apa yang telah ditetapkan sebelumnya. Berdasarkan langkah-langkah yang disampaikan oleh Silalahi diatas sesuai dengan langkah-langkah pengawasan dalam Peraturan Kepala Badan Pengawas Obat dan Makanan tahun 2015-2019.

\section{Makanan Kemasan}

Undang-undang Republik indonesia No.18 tahun 2012 tentang Pangan, menyebutkan bahwa pangan merupakan kebutuhan dasar manusia yang paling utama dan pemenuhannya merupakan bagian dari hak asasi manusia yang dijamin di dalam Undang-Undang Dasar Republik Indinesia 1945 sebagai komponen dasar untuk mewejudkan sumberdaya manusia yang berkualitas.

Undang-undang

Republik

Indonesia Nomor 18 Tahun 2012 tentang 


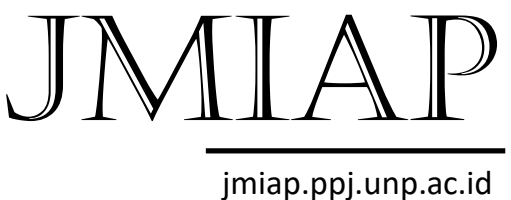

jmiap.ppj.unp.ac.id
ILMU ADMINISTRASI PUBLIK

Email : jianfis.unp@gmail.com

Vol.1 No.1 Tahun 2018 pangan juga menjelaskan bahwa kemasan makanan adalah bahan yang digunakan untuk membungkus atau untuk mewadahi pangan baik yang langsung bersentuhan langsung dengan pangan ataupun tidak. Berdasarkan Undang-undang diatas, makanan kemasan adalah makanan yang sudah di olah dan dikemas dan dibungkus dengan rapi, aman, bersih dan mempunyai kode-kode tertentu dan mempunyai masa kadaluarsa untuk dijual dalam jangka waktu yang diperkirakan.

\section{Kendala dan Upaya dalam Pengawasan}

Kendala merupakan suatu halangan atau rintangan yang menghalangi suatu pencapaian tujuan sebuah organisasi. Kendala dibagi menjadi dua jenis yaitu kendala internal merupakan kendala yang berasal dari dalam organisasi itu sendiri yang membuat pengawasan menjadi terhalang, sedangkan kendala eksternal merupakan kendala atau rintangan yang datangnya dari luar organisasi.

Adapun kendala-kendala lain yang dihadapi oleh BPOM dalam pengawasannya yaitu seperti yang di ungkapkan oleh Dathu Berlan Devanda (2017) adalah: (a) Sistem pengawasan, pengawasan BPOM di Kota Padang yang dilakukan secara berkala dan acak, sehingga menyebabkan pangan yang beredar lepas dari pengawasan, (b) Kurang dipatuhinya perauran oleh pelaku usaha seperti tidak jelasnya informasi yang tertera pada label dan kemasannya, (c) Keterbatasan SDM untuk melakukan pengawasan, (d) Luasnya wilayah kerja BPOM sehingga pengawasan terhadap distributor tidak terjangkau ke seluruh wilayah, (d) Kurangnya pengawasan dan koordinasi terhadap pabrik. (e) Masih rendahnya kesadaran hukum masyarakat selaku konsumen untuk melakukan pengaduan kepada lembaga yang berwewenang bahwa adanya produk yang tidak layak untuk dikonsumsi atau tidak layak edar.

Selanjutnya kendala-kendala BPOM dalam pengawasan yang di ungkapkan oleh Mona Vonica Sari (2017) adalah: a) Masih adanya produk yang masuk untuk dipasarkan tanpa secara jelas distributornya, b) Kesadaran produsen dan penjual yang masih sangat kurang sehingga barang-barang tersebut terus diproduksi, c) Kesadaran konsumen masih kurang karna dipengaruhi oleh ikalan sehinnga mudah terpengarauh dan tanpa memikirkan kesehatan, d) Tingkat pengetahuan pemilik toko masih rendah sehingga mereka belum bisa membedakan mana produk yang layak untuk dikonsumsi dan diedar, e) Pemilik toko tidak bisa menerima jika produkproduk tersebut di musnahkan karna kurngnya pengetahuan dan takaut adanya kerugian, e) Keterbatasan jumlah tenaga kerja untuk mengontrol seluruh wilayah di Kota Padang, f) Kurangnya partisipasi aparat penegak hukum yang berwewenang dalam hal tersebut.

Adapun upaya untuk meminimalisir kendala dalam pengawasan adalah seperti yang di ungkapkan oleh Mona Vonica Sari (2017) yaitu : (a) Melakukan tindakan pemeriksaan atau melakukan razia ke lapangan bersama instansi terkait, terhadap produk yang berbahaya, (b) Merankul semua instansi terkait untuk bersama-sama melakukan pengawasan terhadap produk yang berbahaya, (c) Membawa kepengadilan bagi penjual yang masi melakukan pelanggaran atau masih menjual produk berbahaya kepada konsumen walaupun sudah mendapat teguran dari pihak BBPOM, (d) BBPOM memberi penyuluhan kepada masyarakat tentang produk yang berbahaya. 


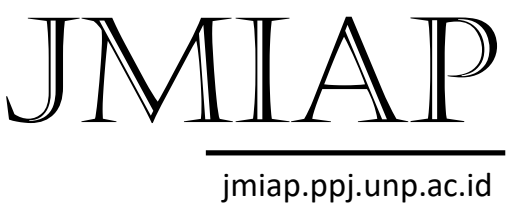

jmiap.ppj.unp.ac.id
ILMU ADMINISTRASI PUBLIK

Email : jianfis.unp@gmail.com

Vol.1 No.1 Tahun 2018

\section{Metode Penelitian}

Jenis penelitian ini adalah kualitatif dengan pendekatan deskriptif. Penelitian ini dilakukan di Balai Pengawas Obat dan Makanan (BBPOM) di Padang yang beralamat di Jln. Gajah Mada, Gunung Pangilun, Kec. Nangaalo Kota Padang. Data dikumpulkan dengan metode purposive sampling yaitu dengan menentukan informan yang dianggap dapat memeberikan informasi secara lengkap.Data dikumpulkan dengan metode purposive sampling yaitu menetukan informan dengan pertimbangan tertentu yang dianggap dapat memberikan informasi secara lengkap dan maksimal. Informan dari penelitian ini merupakan pihak-pihak yang memiliki informasi lengkap sesuai kebutuhan peneliti.

Jenis dan sumber data dalam penelitian ini adalah data primer dan data sekunder. Data primer dalam penelitian ini diperoleh melalui diperoleh melalui wawancara dan observasi yang berkaitan dengan pengawasan kelayakan makanan kemasan di Kota Padang. Sedangkan data sekunder diperoleh melalui dokumendokumen seperti peraturan perundangundanagn yangberkaitan dengan penelitian ini. Keabsahan data dilakukan denagan menggunakan teknik triangulasi sumber dan kecukupan referensi. Triangulasi digunakan untuk mencoccokkan sumber yang penulis peroleh dari wawancara, observasi, dan studi kepustakaan, sedangkan kecukupan eferensi digunakan untuk mendukung data yang peneliti temukan agar data yang peneliti temukan dapat dipercaya.

\section{Hasil Penelitian dan Pembahasan}

\section{Pengawasan BBPOM terhadap kelayakan makanan kemasan di Kota Padang}

Kegiatan pengawasan terhadap peredaran makanan kemasan memang merupakan tugas utama dan tanggung jawab BBPOM, adapun yang diawasi oleh BBPOM adalah label (keterangan nama produk, komposisi, berat bersih, nama alamat yang memproduksi, batas waktu kadaluarsa, label halal), wadah atau keamanan makanan, penempilan fisik makanan baik bentu, warna maupun bau, dan pemeriksaan kimia dan mikrobiologi.

Dari hasil penelitian yang dilakukan di BBPOM di padang untuk melakukan pengawasan terhadap makanan kemasan yang beredar BBPOM melakukan dua tahap pengawasan yaitu pengawasan pre market dan pengawasan post market.

Pengawasan pre-market merupakan pengawasan yang dilakukan sebelum makanan kemasan beredar dan dikonsumsi oleh nmasyarakat. Sistem pengawasan premarket ini dilakukan oleh BBPOM untuk makanan kemasan yang diprodukdi di Padang. Pengawasan pre market ini dilakukan dengan cara pendaftaran izin usaha oleh pelakuku usaha dan pengujian laboraturium bahan yang akan digunakan oleh pelaku usaha, uji laboraturium ini dilakukan di BBPOM di Padang. Pre market ini dilakukan untuk mencegah terjadinya penyelewengan penggunaan bahan makanan yang berbahaya atau yang berlebihan.

Pengawasan post market merupakan pengawasan yang dilaukan selama makanan kemasan beredar.Pengawasan Post market ini dilakukan selama makanan kemasan beredar baik yang produk padang maupun produk luar padang, Pengawasannya post market dilakukan oleh seluruh Balai POM.

Desi Arisanti, Dasman Lanin, Jumiati $\mid 20$ 


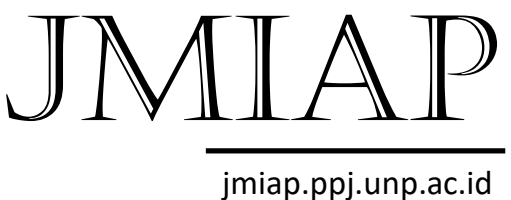

jmiap.ppj.unp.ac.id
ILMU ADMINISTRASI PUBLIK

Email : jianfis.unp@gmail.com Vol.1 No.1 Tahun 2018
Dalam melaksanakan pengawasan makanan kemasan pada distributor, BBPOM melakukan pemeriksaan atau razia secara langsung dilapangan, pemeriksaan dilakukan secara random sampling.

Jika dalam pengawasan post market ini petugas menemukan makanan kemasan yang kadaluarsa petgah hanya menginstruksikan kepemilik toko untuk menyisihkan makanan tersebut untuktidak dijual lagi dan menggembalikan ke distributornya, jika BBPOM menemukan makanan yang tanpa izin edar petugas langsung menarik barang tersebut dan membawa barang tersebut ke BBPOM untuk dimusnahkan. untuk pertemuan pertama BBPOM hanya memberi teguran kepada pemilik toko karena sudah melangar aturan, untuk pertemuan ke dua jika BBPOM masih menemukan barang tang tidak layak untuk dikonsumsi maka BBPOM mengeluarkan sanksi administratif berupa surat peringatan.

Tahap dan jenis pengawasan yang sudah dilakukan oleh Balai Besar Pengawasa Obat dan makanan (BBPOM) ini adalah pengawasan sebelum dan sedang berlangsungnya sebuah pekerjaan. Hal ini sesuai dengan yang disampaikan oleh Sutarto (2012) dalam bukunya yang berjudul Dasar-dasar kepemimpinan administrasiadalah tahap dan jenis pengawasan yaitu pengawasan preventif dan pengawasan reprensif. Pengawasan preventif adalah pengawasan yang dilakukan sebelum penyimpangan terjadi agar atau sebelum sebuah pekerjaan dimulai guna tidak terjadi penyimpangan. sedangkan pengawasan reprensif adalah pengawasan yang dilakukan saat pekerjaan sedang berlangsung, sama halnya yang sudah dilakukan BBPOM dalam melakukan pengawasan yaitu pengawasan post market. pengawasan reprensif ini dilakukan untuk melihat apakah dalam pelaksanaan pekerjaan sedah sesuai dengan apa yang sudah ditetapkan sebelumnya.

Adapun tujuan pengawasan ini dilakukan adalah untuk memastikan makanan yang beredar aman dari bahan yang berbahaya serta menghindari makanan yang berbahaya yang tidak layak untuk dikonsumsi oleh masyarakat, sekaligus melindungi konsumen dari makanan yang berbahaya, karena setiap konsumen berhak mendapatkan perlindungan, sesuai dengan UU No.8 Tahun 1999 tentang perlindunagn konsumen menjelaskan bahwa hak konsumen diantaranya adalah hak atas keamanan, kenyamanan, dan keselamatan dakam mengkonsumsi barang atau jasa, hak untuk memilih barang sesuai dengan nilai tukar dan kondisi serta jaminan yang dijanjikan, hak untuk dilayani dan diperlakukan secara jujur serta tidak diskriminatif, serta hak untuk mendapatkan ganti rugi apabila barang yang diterima tidak sesuai dengan apa yang seharusnya.

Dalam melakukan pengawasan terhadap makanan kemasan yang beredar di tengah masyarakat BPOM masih sering menemukan makan yang kadaluarsa tidak memenuhi standar makanan kemasan. Hal ini akan berdampak buruk kepada pihak distributor yang menjual barang yang bermasalah tersebut. Untuk itu sesuai dengan Perpres No.80/2017 tentang Badan Pengawas Obat dan Makanan, BPOM mempunyai kewenangan menetapkan sanksi secara administratif sesuai pelanggaran yang dilakuan. Adapun sanksi dari pengawasan yang dilakukan BPOM terhadap distributor yang masih menjual barang yang tidak layak untuk di konsumsi adalah: a) Tidak memenuhi standar keamanan makanan, berdasarkan uu no 18 


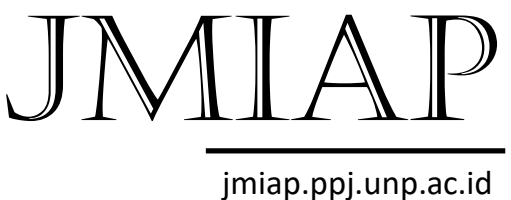

jmiap.ppj.unp.ac.id
ILMU ADMINISTRASI PUBLIK

Email : jianfis.unp@gmail.com Vol.1 No.1 Tahun 2018

tahun 2012 tentang pangan menyatakan bahwa setiap orang yang memproduksi dan memperdagangkan pangan yang dengan sengaja tidak memenuhi standar keamanan pangan maka akan di pidana penjara paling lama 2(dua) tahun atau denda paling banyak 4 milyar, b) Tidak memiliki izin edar, berdasarkan uu no 18 tahun 2012 tentang pangan pasal 142 menyebutkan bahwa setiap pelaku usaha yang dengan sengaja tidak memiliki izin edar terhadap pangan atau makanan kemasan yang beredar akan dipidan penjara paling lama 2 tahun atau denda sebesar 4 milyar.

Waktu yang digunakan oleh BBPOM untuk melakukan pengawasan adalah sesuai dengan yang disampiakan oleh Hasibuan (2001) yaitu Preventif Controll dan Represive controll. Preventive controll merupakan pengendalian atau pengawasan yang dilakukan sebelum kegiatan dilakukan untuk menghindari terjadinya penyimpangan-penyimpangan dalam pelaksanaannya. Preventive ini dilakukan dengan cara:

a. Menentukan proses pelaksanaan pekerjaan. Hal ini sama dengan yang dilakukan BBPOM yaitu melakukan pemeriksaan laboraturium bahanbahan makanan yang akan produsen jual, setelah hasil laboraturium keluar dan dinyatakan aman serta surat izin produksi sudah dikeluarkan makan produsen boleh memproduksi makanan kemasan tersebut.

b. Membuat peraturan dan pelaksanaan pekerjaan. dalam pengawasan BBPOM juga membuat berbagai peraturan, baik peraturan presiden, peraturan pemerintah ataupun peraturan kepala BPOM itu sendiri. Peraturan ini dubuat baik untuk pengawas ataupun untuk yang diawasi itu sendiri. c. Mengorganisasi segala macam kegiatan.

d. Menentukan jabatan, job description, authority dan responsibility bagi setiap individu karyawan.

e. Menetapkan sistem koordinasi pelaporan dan pelaksanaan. Sama dengan halnya yang dilakukan oleh BBPOM dalam melakukan pengawasan BBPOM melakukan pengawasan kelapangan satu bulan sekali dan pengawasan itu tidak ditentukan tanggalnya. Oengawasan dilakukan secara mendadak diberbagai toko yang ada di Kota Padang.

f. Menetapkan sanksi-sanksi bagi karyawan yang membuat kesalaha. Sanksi juga diberikan kepada pemilik toko atau distributor yang melanggar peraturan, contohnya saja seperti surat teguran atau surat peringatan.

Preventive controll, merupakan pengendalian yang baik karana dilakukan sebelum penyimpangan terjadi.Preventive controll ini dilakukan dengan menetapkan beberapa cara sebelum pengawasan dilaksanakan. Selanjutnya waktu yang digunakan BBPOM untuk melakukan pengawasan adalah Repressive controll, merupakan pengendalian yang dilakukan sesudah rerjadinya kesalahan atau penyelewengan dalm pelaksanaan, dengan maksud agar tidak terjadi pengulangan kesalahan, sehingga hasilnya sesuai dengan yang diinginkan. Repressive controll dilakukan dengan cara sebagai berikut :

a. Membandingkan hasil dengan rencana.

b. Menganalisis sebab-sebab yang menimbulkan kesalahan dan mencari tindakan perbaikannya.

c. Memberikan penilaian terhadap pelaksanaannya, jika perlu diberi sanksi hukum kepadanya. 


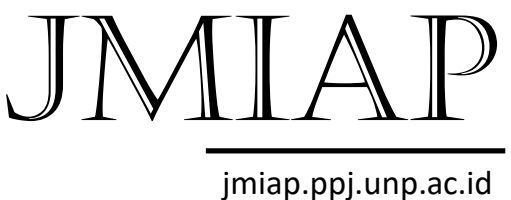

jmiap.ppj.unp.ac.id
ILMU ADMINISTRASI PUBLIK

Email : jianfis.unp@gmail.com Vol.1 No.1 Tahun 2018 d. Menilai kembali pelaksanaan prosedurprosedur yang ada.

e. Mengecek kebenaran laporan yang dibuat yang dibuat oleh petugas pelaksana.

f. Jika perlu meningkatkan keterampilan atau kemampuan pelaksanaan melalui training atau education.

Upaya pengawasan ini adalah untuk mencegah terjadinya pelangarann hukum dan pengawasan sekaligus menghindari penyelewengan dan sekaligus untk memperbaiki penyelewengan jika sudah terjadi. Dengan demikian, hasil penelitian ini dapat membuktikan dan mendukung teori yangdikemukakan oleh Henry Fayol yang mengatakan bahwa pengawasan sebagai suatu tindakan meneliti atau melihat apakan suatu kegiatan kebijakan sesuai dengan yang telah ditetapkan dan pengawasan ini dilakukan untuk menemukan kelemahan-kelemahan dan penyelewengan tersebut bisa diperbaiki dan diatasi secepet mungkin dan mencegah kelemahan dan penyelewengan terulang lagi.

\section{Kendala BBPOM dalam Pengawasan}

Kendala merupakan suatu halangan atau rintangan yang menghalangi suatu pencapaian tujuan sebuah organisasi. Kendala dibagi menjadi dua jenis yaitu kendala internal merupakan kendala yang berasal dari dalam organisasi itu sendiri yang membuat pengawasan menjadi terhalang, sedangkan kendala eksternal merupakan kendala atau rintangan yang datangnya dari luar organisasi.

Dalam menjalankan tugas sebagai pengawas terhadap makanan kemasan BBPOM dituntut untuk melakukan pengawasan semaksimal mungkin, namun dalam pelaksanaan pengawasan terdapat beberapa kendala. Dalam pelaksanaan pengawasan BBPOM terkendala oleh keterbatasan anggaran. Anggaran menurut Halim (dalam Irfan Fatoni, 2013) adalah penghubung antara perencanaan dan pengendalian yang merupakan wujud komitmen untuk mengimplementasikan berbagai perencanaan dan pengendalian yang harus dikerjakan dan sumber daya yang diperlukan, dengan terbatasnya anggaran membuat pengawasan sulit dilakukan keseluruh toko yang ada di Kota Padang, sedangkan toko yang ada di Kota Padang sangat banyak. Kendala selanjutnya adalah kurangnya sumberdaya manusia untuk melakukan pengawasan. Mona vonica Sari (2017) menyatakan kurangnya jumlah tenaga kerja untuk mengontrol secara keseluruhan toko-toko yang ada di Kota Padang, Kota Padang yang wilayahnya relatif luas, hal ini juga membuat pengawasan juga tidak dapat terleksana secara menyleuruh karena banyaknya toko yang ada di Kota Padang. Kurangnya sumberdaya manusia ini juga menjadi kendala untuk melakukan sosialisasi secara langsung kepada masyarakat dan distributor secara maksimal.

Kendala selanjutnya yaitu pemilik toko tidak bisa menerima jika barangnya ditarik oleh BBPOM, seperti yang diungkapkan oleh Mona Vonoca Sari (2017) dalam melakukan pengawasan juga terkendala terhadap pemilik toko yang tidak mau barangnya diambil oleh BBPOM karena takut menimbulkan kerugian, disini terlihat bahwa distributor belum peduli terhadap peraturan dan kesehatan konsumen, setiap konsumen berhak mendapatkan perlindungan, berdasarkan Undang-undang Republik Indonesia Nomor 8 Tahun 1999 tentang perlindungan konsumen bab 3 hak dan kewajiban 


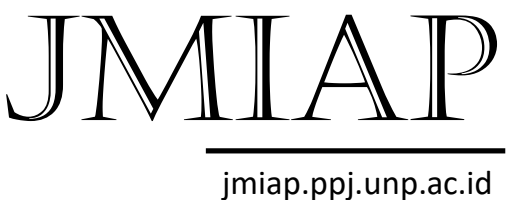

jmiap.ppj.unp.ac.id
ILMU ADMINISTRASI PUBLIK

Email : jianfis.unp@gmail.com

Vol.1 No.1 Tahun 2018 konsumen salah satunya adalah hak atas kenyamanan, keamanan, dan keselamatan dalam mengkonsumsi barang dan jasa. Sikap distributor yang demikian membuat tugas pengawasan dilapangan terkendala untuk melakukan penarikan terhadap barang yang bermasalah, sehingga terjadi percecokan antara tim pengawas BBPOM dengan distributor. Kendala selanjutnya yaitu kurang pedulinya masyarakat terhadap sosialisasi BBPOM, berbagai sosialisasi yang sudah BBPOM lakukan terhadap masyarakat dan distributor, tetapi banyak distributor tidak menghadiri dan tidak peduli terhadap sosialisasi yang diadakan oleh BPOM, sehingga saat melakukan pengawasan dilapangan BBPOM masih menemukan barang yang tidak layak untuk diedar dan tidak layak untuk dikonsumsi.

\section{Upaya ВВРОМ Meminimalisir Kendala Pengawasan}

Adapun upaya yang dilakukan BBPOM untuk meminimalisir kendala keterbatasan anggaran adalah optimalisasi penggunaan anggran, kurangnya anggaran tidak bisa menjadi alasan bagi BBPOM untuk tidak melakukan pengawasa, kendala ini dapat diminimalisir dengan cara menggunakan metode pengawasan sampling dengan melihat makanan yang beresiko tinggi dan menggunakan metode analisa resiko dengan melihat dimana kasus 2 tahun terakhir yang bermasalah atau yang tidak memenuhi ketentuan. Upaya selanjutnya untuk meminimalisir Kurangnya sumber daya manusia dalam melakukan pengawasan, kendala ini tidak bisa menjadi alasan oleh BBPOM untuk tidak melakukan pengawasan. Upaya BBPOM untuk mengatasi hal ini adalah dengan merangkul instansi terkait atau bekerja sama dengan instansi terkait agar peredaran makanan kemasan yang tidak layak untuk diedar tidak lepas dari pengawasan. Mona Vonica Sari (2017) menyatakan bahwa upaya yang dilakukan untuk meminimalisir kendala kurangnya sumber daya manusia adalah dengan merangkul instansi terkait untuk bekerja sama dalam mengawasi peredaran makanan kemasan yang beredar di Kota Padang.

Upaya selanjutnya adalah Memberi teguran adalah cara BBPOM dalam mengahadapi masalah dengan distributor yang tidak mau barangnya ditarik, seperti yang di ungkapkan oleh Mona Vonica Sari (2017) menyatakan bahwa Membawa kepengadilan bagi penjual yang masi melakukan pelanggaran atau masih menjual produk berbahaya kepada konsumen walaupun sudah mendapat teguran dari pihak BBPOM, dengan membawa permasalahan ini ke jalur hukum diharapkan dapat memberi efek jera kepada distributor yang menjual makanan kemasan yang berbahaya. Upaya yang dilakukan BBPOM selanjutnya adalah Merubah metode sosialisai, sosialisasi dilaukan dengan cara publik warning yaitu pemberian informasi melalui media sosial dan media cetak dengan tidak pedulinya masyarakat dan distributor terhadap sosialiasi yang diberikan oleh BBPOM maka penyebaran dan pemberian informasi dilakukan melalui media sosial, media cetak. Dengan cara seperti itu distributor dapat dengan mudah mendapatkan informasi yang dimuat oleh BPOM. Dengan adanya informasi-informasi yang diberikan BBPOM secara online daharapkan konsumen cerdas dalam memilih makanan dan distributor dapat dengan mudah mencari informasi untuk keamanan makanan kemasan yang diproduksinya.

Desi Arisanti, Dasman Lanin, Jumiati $\mid 24$ 


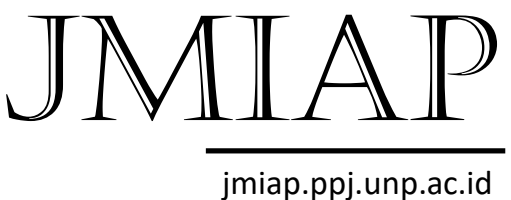

\section{PENUTUP}

\section{Kesimpulan}

Pertama, pengawasan yang dilakukan oleh BBPOM terhadap makanan kemasan yang beredar di Kota Padang dilakukan dua tahap pengawasan, yaitu pengawasan premarket dan pengawasan post-market. pengawasan pre market adalah pengawasan yang dilakukan sebelum makanan kemasan beredar, hal ini dilakukan dengan cara pendaftaran izin usaha ke BBPOM serta pengujian laboraturium bahan-bahan yang akan digunakan untuk makanan kemasan nantinya. Pengawasan post market, yaitu pengawasan yang dilakukan selama makanan kemasan beredar di tengah masyarakat. Pengawasan post market ini dilakukan dengan cara pemeriksaan ketoko atau mini market.

Dalam melakukan pengawasan terhadap makanan kemasan terdapat beberapa kendala yang dihadapi oleh BBPOM yaitu kurangnya anggaran, keterbatasan anggaran membuat BBPOM tidak bisa melakukan pengawasan keseluruh toko, namun hal ini tidak bisa menjadi alasan BBPOM untuk tidak melakukan pengawasan, adapun upaya yang dilaukan BBPOM untuk meminimalisir keterbatasan anggran adalah dengan cara optimalisasi penggunaan anggran dan merubah metode pengawasan yaitu dengancara sampling produk. Kendala yang kedua yaitu kurangnya sumber daya manusia juga membuat BBPOM tidak bisa melakukan pengawasan ke seluruh toko, karena toko yang ada diKota Padang sangat banyak. Upaya untuk menghadapi kendala ini BBPOM melakukannya dengan cara sampling produk dan bekerjasama dengan instansi terkait. Kendala selanjutnya adalah
ILMU ADMINISTRASI PUBLIK

Email : jianfis.unp@gmail.com Vol.1 No.1 Tahun 2018

distributor tidak bisa terima jika barangnya ditarik oleh BBPOM. Upaya yang dilakukan BBPOM untuk masalah ini antara lain adalah dengan memberi surat teguran kepada distributor.

Kendala selanjutnya adalah tidak pedulinya masyarakat terhadap sosialisasi BBPOM, adapun upaya BBPOM untuk meminimalisir kendala tersebut adalah dengan merubah cara sosialisasi, sosialisasi tidak selalu diberikan secara langsung tapi sosialisasi diberikan dan diinformasikan melalui media sosial, media cetak. Agar distributor maupun masyarakat selaku konsumen lebih mudah untuk mendapatkan informasi.

\section{Saran}

Berdasarkan hasil penelitian dengan judul “ Upaya Balai Besar Pengawas Obat dan Makanan (BBPOM) di Padang dalam mengawasi peredaran makanan kemasan" maka peneliti mencoba memberikan saransaran sebagai berikut :

1. Menyusun anggaran sebaiknya memasukkan biaya-biaya tak terduga atau mengajukan peningkatan anggaran untuk transportasi pengawasan, dan mengkai kebutuhan anggaran saat ini dan sebelumnya untuk diajukan untuk penggunaan anggaran tahun selanjutnya.

2. Melakukan penambahan pegawai, karna pengawasan terhadap makanan kemasan yang ada di Kota Padang serta sosialisasi merupakan tantangan serta tanggung jawab bagi BBPOM di Padang, sehingga penambahan pegawai dirasa perlu agar pengawasan terhadap makanan kemasan yang beredar di Kota Padang dapat terlaksana dengan maksimal serta 


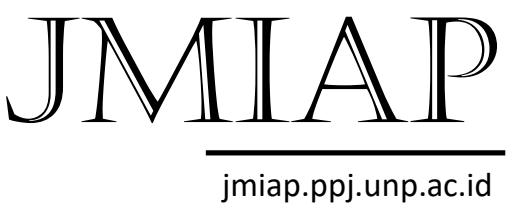

kinerja BBPOM dapat berjalan dengan optimal.

3. Memberikan pengertian kepada distributor kalau makanan yang dia jual adalah dapat merusak kesehatan konsumen. Serta menegakkan hukum yang telah ditetapkan untuk pelaku usaha yang masih membuat pelanggaran.

4. Lebih banyak melakukan sosialisasi melalui media sosial tidak hanya dari website BBPOM, memberikan sosialisasi melalui facebook, twitter, youtube, selain dapat menghemat anggaran masyarakat juga dapat lebih mudah mengetahui informasiinformasi mana produk yang boleh dikonsumsi dan mana produk yang menggunakan bahan berbahaya melalui media sosial. Selain itu juga dapat membantu mempermudah pengawasan BBPOM.

\section{DAFTAR KEPUSTAKAAN}

Malayu S.P Hasibusn. 2011. Manajemen: Dasar, Pengertian, dan Masalah. Jakarta: Bumi Aksara.

Ulbert Silalahi. 1999. Studi Tentang Ilmu Administrasi:konsep,teori \& dimensi.

Bandung: sinar baru algensindo.

Sutarto.2012.Dasar-Dasar Kepemimpinan administrasi.Gajah Mada University

Press.

Henki Idris Issakh \& Zahrida Wiryawan. 2014. Pengantar Manajemen. In Media. Torang, Syamsir. 2013. Organisasi \& Manajemen: Perilaku, Struktur, Budaya \&

Perubahan Organisasi. Bandung: Alfabeta.

Sugiyono. 2012. Memahami penelitian kualitatif. Bandung: Alfabeta.
ILMU ADMINISTRASI PUBLIK

Email : jianfis.unp@gmail.com Vol.1 No.1 Tahun 2018

\section{Jurnal/Artikel}

Gaery Rahman Saputra. 2014. Pengawasan

Balai Pengawas Obat dan Makanan (BPOM) Provinsi Banten

dalam Peredaran Obat Tradisional di Kota Serang. skripsi Program Studi

Ilmu Administrasi Negara Konsentrasi Manajemen Publik. Universitas Sultan Ageng Tirtayasa.

Mona Vonica Sari. 2017. Pengawasan Oleh Balai Pengawas obat dan Makanan (BPOM) Terhadap Kosmetik

Balai Berbahaya di Kota Padang. Univesitas Bung Hatta.

Dathu Berlan Devanda. 2017. Peran Badan Pengawas Obat dan Makanan (BPOM) Terhadap Pelaku Perdagangan ObatObatan Tanpa Mencantumkan Izin dan Tanggal Kadaluarsa. Universitas Bung Hatta.

Fantoni, irfan.2013. Pengaruh Anggaran dan Pengendalian Terhadap Aktifitas Kinerja Satuan Kerja Perangkat Daerahdi Kabupaten Malang, Malang; Jurnal Manajemen dan dan Akuntansi, Vol2 No 3

\section{Peraturan-Peraturan}

Peraturan Presiden Republik Indonesia nomor 80 tahun 2017 tentang Badan

Pengawas Obat dan Makanan.

Keputusan Kepala Badan Pengawas Obat dan Makanan Nomor:

020001/SK/KBPOM tentang

Organisasi dan tata kerja Badan Pengawas Obat dan Makanan.

Peraturan Menteri Kesehatan Republik indonesia Nomor 30 tentang pencantuman kandungan gula, garam, dan lemak serta pesan kesehatan untuk pangan olahan dan pangan siap saji. 
JMIAP
ILMU ADMINISTRASI PUBLIK

Email : jianfis.unp@gmail.com Vol.1 No.1 Tahun 2018

Undang-undang Republik Indonesia

Nomor 18 tahun 2012 tentang Pangan

Renstra BBPOM di Padang Tahun 20152019.

Peraturan Kepala Badan Pengawas Obat dan Makanan RI Nomor 12 Tahun 2016

tentang pendftaran pangan olahan.

Peraturan Kepala Bdan Pengawas Obat dan

Makanan Republik Indonesia Nomor

2 Tahun 2015 Tentang Rencana

Strategis Badan Pengawas Obat dan

Makanan.

Peraturan Kepala Badan Pengawas Obat dan Makanan No 14 Tahun 2014 tentang Unit Pelaksana Teknis dibidang Pengawas Obat dan Makanan. 